\title{
Theoretical Investigation on Performance Enhancement of CIGS Based Solar Cells
}

\author{
B. Barman*, P.K. Kalita \\ Rajiv Gandhi University, Doimukh, Arunachal Pradesh 791112, India
}

(Received 26 September 2020; revised manuscript received 20 December 2020; published online 25 December 2020)

\begin{abstract}
The main objective of this work is to investigate the CIGS solar cell performance by replacing the toxic CdS buffer layer from the conventional solar cell structure Ag/ITO/ZnO/CdS/CIGS/W by the non-toxic ZnSe layer using SCAPS-1D software. $J$ - $V$ characteristics of the simulated cell structure show that the efficiency of the solar cell increases from $23.23 \%$ to $23.58 \%$ (with $V_{o c}$ of $0.8202 \mathrm{~V}, J_{s c}$ of $34.86 \mathrm{~mA} / \mathrm{cm}^{2}$ and FF of $82.49 \%$ ) due to the use of ZnSe layer. The increase in the efficiency of the cell is attributed to the decrease in photon absorption in the buffer layer due to higher band gap of ZnSe. An additional thin layer was inserted between CIGS and the back contact (W) to eliminate the back surface recombination. This new layer provided an additional hole tunneling action which led to an increase in the solar cell efficiency up to $24.64 \%$. Moreover, an attempt has been made to investigate the dependence of the CIGS solar cell efficiency on the operating temperature.
\end{abstract}

Keywords: CIGS, Buffer layer, Back surface layer, Temperature, SCAPS-1D.

\section{INTRODUCTION}

Till date, CIGS has been one of the potential candidates for photovoltaic applications because of its tunable band gap (1.04 eV to $1.7 \mathrm{eV}$ ) and high absorption coefficient [1]. Various researches have been done to develop the CIGS based solar cells over the years. But the development is hindered by the materials cost and efficiency of solar cells. Therefore, to overcome these problems (cost, efficiency and lifetime) researchers have been working hard on various materials for the last few decades [2]. At present, the highest efficiency of the conventional baseline structured CIGS solar cell in laboratory conditions reaches $22.67 \%$ for the thickness of $3 \mu \mathrm{m}$ [3]. The composition materials, i.e. gallium and indium, of the CIGS are very rare and expensive. Therefore, an attempt has been made to reduce the use of Ga and In by reducing the absorber layer thickness. This can be done by using another $p$-type thin layer between CIGS and the metal back contact electrode. This new layer will provide additional hole tunneling as well as reduce back surface recombination $[4,5]$. The main component of the solar cell is the $p$ - $n$ junction, which is formed by $n$-type buffer layer and $p$-type absorber layer. Different efficiency has been reported by various groups on the conventional and traditional layers of CdS materials till date. But it has some limitations due to the presence of toxic $\mathrm{Cd}$ material in the $\mathrm{CdS}$ buffer layer. However, different non-cadmium and non-toxic materials such as $\mathrm{ZnS}, \mathrm{Zn}(\mathrm{O}, \mathrm{OH})$ and $\mathrm{In}_{2} \mathrm{~S}_{3}$ were used as a buffer layer and investigated [6, 7]. The aim of this work is to improve the efficiency of the solar cell by replacing the CdS layer with a wider-gap ZnSe layer. A comparative study was made theoretically for $\mathrm{CdS}$ and ZnSe as buffer layers for the proposed cell using a simulation software, since it is important to analyze and optimize the device parameters prior to the experimental work to improve the device performance.

\section{DESIGN AND SIMULATION}

The design prepared for this work is shown in Fig. 1. A $p$-CIGS absorber layer with a band gap of $1.3 \mathrm{eV}$ and $n$-CdS layer with a band gap of $2.4 \mathrm{eV}$ or $n$-ZnSe layer with a band gap of $2.58 \mathrm{eV}$ were used for the proposed cell. These $p$-type and $n$-type layers will form a heterojunction and facilitate the photovoltaic effect. $n-\mathrm{ZnO}$ is used for the window layer with a band gap of $3.3 \mathrm{eV}$ to promote absorption of photons. A $p$ - $\mathrm{PbS}$ layer with a band gap of $1.4 \mathrm{eV}$ is used as the back sulfur layer to enhance the performance of the solar cell [8].

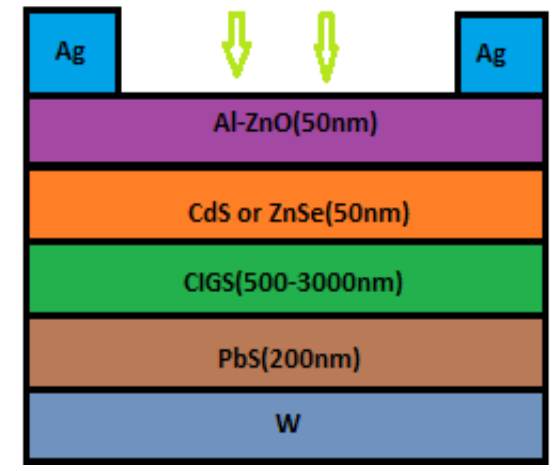

Fig. 1 - Schematic diagram of the proposed cell

In this study, we use the solar cell capacitance simulator structures (SCAPS-1D) to analyze and optimize the various parameters of the proposed CIGS-based solar cells. SCAPS is a one-dimensional solar cell device simulator, developed at ELIS, University of Gent, which is freely available to the PV research community. It can calculate steady-state energy band diagram, interface recombination and carrier transport based on the Poisson equation and continuity equation for both holes and electrons. The equations are

\footnotetext{
*barman.barnali3@gmail.com
} 
Table1 - Input materials parameters of the proposed cell

\begin{tabular}{|c|c|c|c|c|c|}
\hline Parameters & CIGS & $\mathrm{CdS}$ & $\mathrm{ZnSe}$ & $\mathrm{ZnO}$ & $\mathrm{PbS}$ \\
\hline Thickness (nm) & 3000 & 50 & 50 & 50 & 200 \\
\hline Band gap $(\mathrm{eV})$ & 1.3 & 2.4 & 2.58 & 3.3 & 1.4 \\
\hline $\begin{array}{l}\text { Electron } \\
\text { affinity }(\mathrm{eV})\end{array}$ & 4.5 & 4.45 & 4.45 & 4.55 & 4.35 \\
\hline $\begin{array}{l}\text { Dielectric } \\
\text { constant }\end{array}$ & 13.6 & 10 & 8.1 & 9 & 10 \\
\hline $\begin{array}{l}\text { CB density of } \\
\text { states }\left(\mathrm{cm}^{-3}\right)\end{array}$ & $2 \cdot 10^{18}$ & $2.10^{18}$ & $2 \cdot 10^{18}$ & $4.10^{18}$ & $2 \cdot 10^{18}$ \\
\hline $\begin{array}{l}\text { VB density of } \\
\text { states }\left(\mathrm{cm}^{-3}\right)\end{array}$ & $1.8 \cdot 10^{18}$ & $1.5 \cdot 10^{18}$ & $1.5 \cdot 10^{18}$ & $9.10^{18}$ & $2 \cdot 10^{18}$ \\
\hline $\begin{array}{l}\text { Hole mobility } \\
\left(\mathrm{cm}^{2} / \mathrm{V} \cdot \mathrm{s}\right)\end{array}$ & 100 & 100 & 100 & 100 & 20 \\
\hline $\begin{array}{l}\text { Electron mobil- } \\
\text { ity }\left(\mathrm{cm}^{2} / \mathrm{V} \cdot \mathrm{s}\right)\end{array}$ & 20 & 20 & 20 & 20 & 100 \\
\hline $\begin{array}{l}\text { Donor density } \\
\left(\mathrm{cm}^{-3}\right)\end{array}$ & - & $10^{19}$ & - & $5.10^{20}$ & - \\
\hline $\begin{array}{l}\text { Acceptor } \\
\text { density }\left(\mathrm{cm}^{-3}\right)\end{array}$ & $5.5 \cdot 10^{16}$ & - & - & - & $5.5 \cdot 10^{16}$ \\
\hline
\end{tabular}

$$
\begin{gathered}
\frac{d^{2}}{d x^{2}} \Psi(x)=\frac{e}{\varepsilon_{0} \varepsilon_{r}}\left(p(x)-n(x)+N_{D}-N_{A}+\rho_{p}-\rho_{n},\right. \\
\frac{d}{d x^{2}} J_{n}(x)-e \frac{\partial \varpi(x)}{\partial t}-e \frac{\partial \rho_{n}}{\partial t}=G(x)-R(x), \\
\frac{d}{d x^{2}} J_{p}(x)+e \frac{\partial p(x)}{\partial t}+e \frac{\partial \rho_{n}}{\partial t}=G(x)-R(x),
\end{gathered}
$$

where $\Psi(x)$ is the electrostatic potential, $e$ is the electric charge, $\varepsilon_{0}$ and $\varepsilon_{r}$ are vacuum and relative permittivities, $p$ and $n$ are the concentrations of holes and electrons, $N_{D}$ and $N_{A}$ are the donor and acceptor densities, $\rho_{p}$ and $\rho_{n}$ are the distributions of holes and electrons, $J_{n}$ and $J_{p}$ are the electron and hole densities, $G(x)$ and $R(x)$ are the generation and recombination rates, respectively. The simulation work for the two designed cells has been done by fitting the standard physical parameters of the materials collected from previously published papers $[6,9,10]$. All the input parameters are listed in Table 1.

\section{RESULTS AND DISCUSSION}

The resulting $J-V$ characteristics of CIGS solar cells under dark and illumination are shown in Fig. 2a for the thickness of $3 \mu \mathrm{m}$. The $J-V$ characteristics result with two different $n$-type buffer layers, i.e. $n$-CdS and $n$-ZnSe, which are also shown in Fig. 2b. All the electrical parameters obtained from the $J-V$ characteristics are summarized in Table 2 . From Table 2 it can be clearly observed that there are minor differences in the $V_{o c}, J_{s c}$ and efficiency values. But the major difference is observed in the fill factor values, i.e. $77.91 \%$ in case of CdS and $82.41 \%$ in case of ZnSe layer.

The difference in the electrical parameters can be understood from the difference in the energy band gap for the proposed cells. The value of $\Delta E_{v}$ is higher in case of $n$-ZnSe compared to the $n$-CdS layer. The higher $\Delta E_{v}$ will prevent the electron-hole recombination at the interface. Therefore, $V_{o c}, \mathrm{FF}$ and efficiency of the device increase after replacing CdS layer by ZnSe layer. Moreover, the increase in the device performance for the ZnSe layer can be understood from the quantum effi- ciency graph as shown in Fig. 3. The spectral response for the proposed solar cells with CdS and ZnSe buffer layers is almost identical in the long wavelength range of 450-950 nm. But in the short wavelength range 300$450 \mathrm{~nm}$, a noticeable difference was observed in the QE value. This indicates that the band gap of CdS starts to absorb light of wavelength below $450 \mathrm{~nm}$ because of the lower band gap value compared to $\mathrm{ZnSe}$.
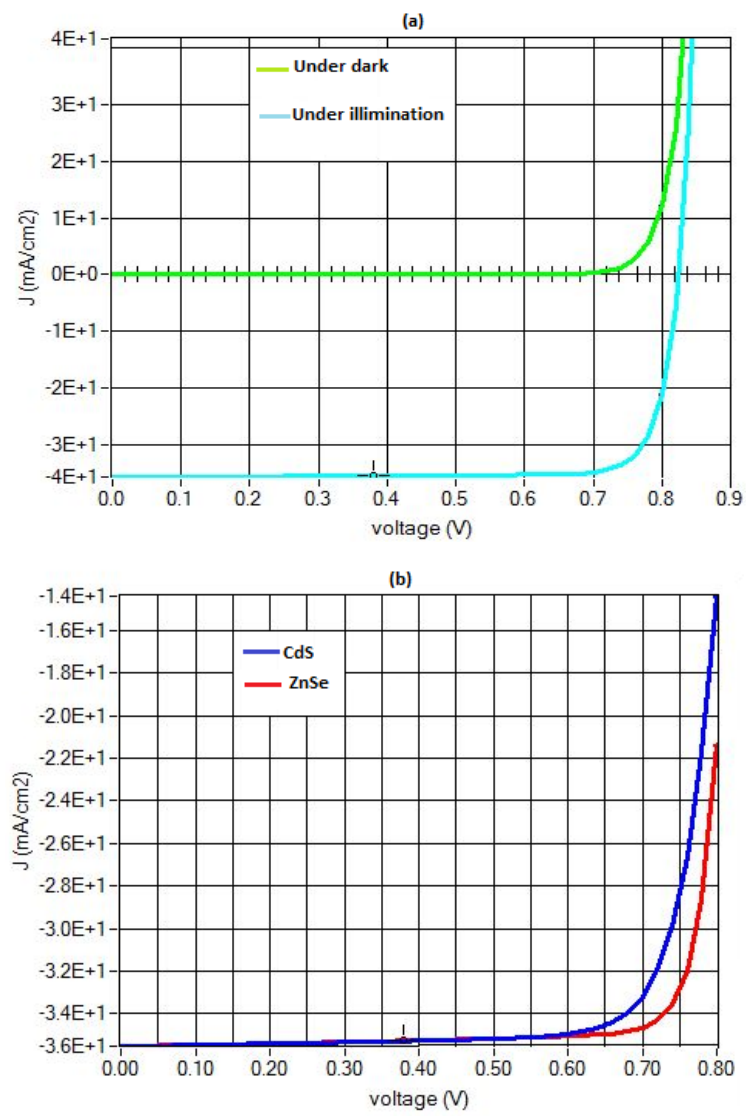

Fig. $2-J-V$ characteristics under (a) dark and (b) illumination with CdS and ZnSe buffer layers of the cell

Table 2 - Electrical parameters of CdS and ZnSe buffer layers

\begin{tabular}{|c|c|c|c|c|}
\hline Buffer layer & $V_{o c}(\mathrm{~V})$ & $J_{s c}\left(\mathrm{~mA} / \mathrm{cm}^{2}\right)$ & FF (\%) & २ (\%) \\
\hline $\mathrm{CdS}$ & 0.8199 & 35.52 & 77.81 & 23.23 \\
\hline $\mathrm{ZnSe}$ & 0.8202 & 34.86 & 82.49 & 23.85 \\
\hline
\end{tabular}

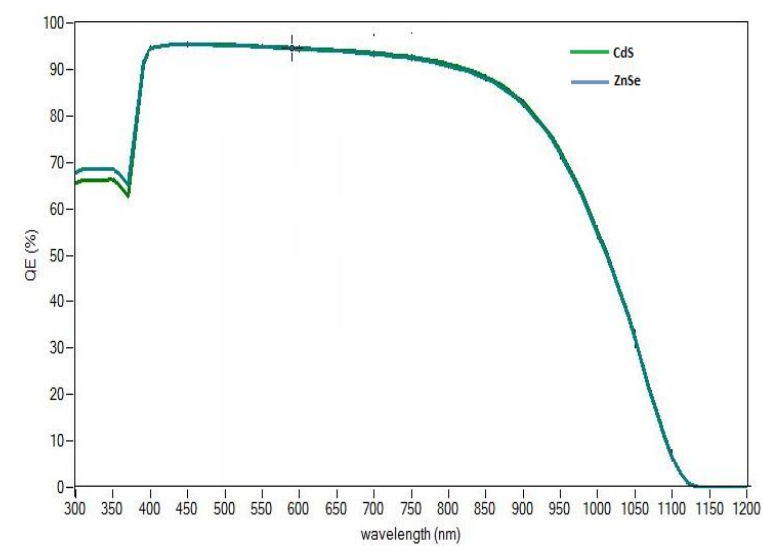

Fig. 3 - QE graph for the proposed cells with CdS and ZnSe layers 

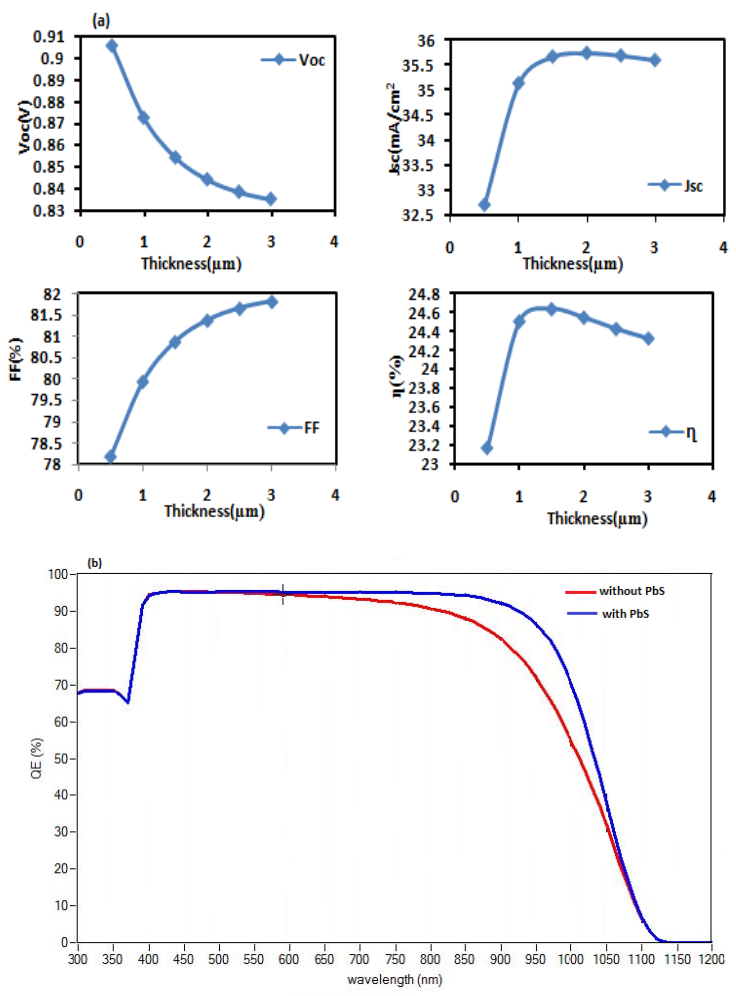

Fig. 4 - BSF layer effect on (a) electrical parameters w.r.t CIGS thickness, (b) quantum efficiency

\subsection{Insertion of $\mathrm{BSF}(\mathrm{PbS})$ Layer}

An additional $p$-type $(\mathrm{PbS})$ thin layer of a thickness of $200 \mathrm{~nm}$ suggested by Sayed et al. [11] was inserted between the CIGS layer and the back electrode to reduce the possible recombination loss and barrier height of the proposed cell. This additional layer will act as a back surface reflector, which will reflect back the electrons from the CIGS layer and thus contribute to the cell performance. From Fig. 4a, it is obvious that the cell efficiency increases up to $24.66 \%$ for the $\mathrm{PbS}$ layer thickness of $1.5 \mu \mathrm{m}$, after that efficiency decreases upon further increase in the CIGS thickness. However, the efficiency of $23.58 \%$ was achieved for the thickness of $3 \mu \mathrm{m}$.

\subsection{Effect of the Operating Temperature on the Electrical Parameters}

The use of low-cost $\mathrm{PbS}$ layer will reduce the use of Ga and In in the device which will eventually lead to the decrease in the production cost. QE has been enhanced after the insertion of the BSF layer due to the increase in photons collection at longer wavelengths ranging from $450 \mathrm{~nm}$ to $1000 \mathrm{~nm}$ on a high level of approximately $95 \%$.

The operating temperature plays a crucial role and affects the performance of the solar cell. In this work, operating temperature has been varied from $300 \mathrm{~K}$ to $360 \mathrm{~K}$ for both CdS and ZnSe buffer layers. Electrical parameters from Fig. 5 show that both layers follow the same trend if temperature is increased. The decrease in the device performance may be due to the increase in the electron-hole recombination rate. This increase in the recombination rate decreases $V_{o c}$ and $\mathrm{FF}$ that will lead to the overall decrease in the cell efficiency.
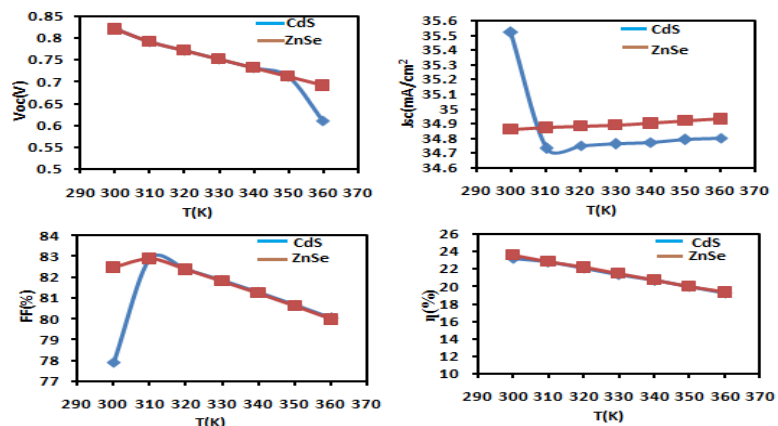

Fig. 5 - Effect of temperature variation on the electrical parameters for different buffer layers

\section{CONCLUSIONS}

The cell performance of the proposed solar cell was improved up to the efficiency of $23.58 \%$ after replacing the CdS buffer layer by Cd free ZnSe layer for a CIGS thickness of $3 \mu \mathrm{m}$. Moreover, cell performance can be achieved up to $24.66 \%$ by adding an additional layer between CIGS and the back contact (W). The addition of this layer reduces the use of Ga and In materials in the solar cell. The study reveals that an increased operating temperature can degrade the device performance significantly. Therefore, it is important to maintain the optimum operating temperature for better performance of the solar cell. All the findings from this work are quite promising to carry out further experimental works.

\section{ACKNOWLEDGEMENTS}

The authors sincerely thank to Dr. Marc Burgelman from the University of Gent for providing SCAPS-1D simulation software.

\section{REFERENCES}

1. O. Cojocaru-Miredin, P. Choi, R. Wuerz, D. Raabe, Appl. Phys. Lett. 101, 181603 (2012).

2. M. Schmid, Semicond. Sci. Technol. 32, 043003 (2017).

3. P. Jackson, R. Wuerz, D. Hariskos, E. Letter, W. Write, M. Powalla, phys. status solidi (RRL) 10 No 8, 583 (2016).

4. Hao-yu Sun, Peng-hai Li, Yu-ming Xue, Zai-xiang Qiao, Sai Liu, Optoelectron. Lett. 15 No 6, 428 (2019).

5. S. Benabbas, H. Heriche, Z. Rouabah, N. Chelali, 2014 North African Workshop on Dielectic Materials for Photovoltaic Systems (NAWDMPV) (2014).
6. Bechlaghem Sara, Zebentout Baya, Benamara Zineb, Mater. Sci.-Poland 36 No 3, 514 (2018).

7. M. Mostefaouia, H. Mazaria, S. Khelifia, A. Bouraioua, R. Daboua, Energy Procedia 74, 736 (2014).

8. Samar Dabbabi, Tarek Ben Nasr, Najoua Kamoun-Turki, Result. Phys. 7, 4020 (2017).

9. Mohamed Wahid Bouabdelli, Fatiha Rogti, Mostefa Maache, Abdelaziz Rabehi, Optik 216, 164948 (2020).

10. Jaymin Ray, Tapas K. Chaudhuri, Chetan Panchal, Kinjal Patel, Keyur Patel, Gopal Bhatt, Priya Suryavanshi, J. Nano- 
Electron. Phys. 9 No 3, 03041 (2017)

11. Sayed Rezwanul Islam Biplab, Md. Hasan Ali, Md. Maha- bub Alam Moon, Md. Firoz Pervez, Md. Ferdous Rahman, Jaker Hossain, J. Comput. Electron. 19, 342 (2019).

\title{
Теоретичне дослідження вдосконалення продуктивності сонячних елементів на основі CIGS
}

\author{
B. Barman, P.K. Kalita \\ Rajiv Gandhi University, Doimukh, Arunachal Pradesh 791112, India
}

\begin{abstract}
Основна мета роботи - дослідити ефективність сонячного елемента на основі CIGS, замінивши токсичний буферний шар $\mathrm{CdS}$ звичайної структури сонячного елемента $\mathrm{Ag} / \mathrm{ITO} / \mathrm{ZnO} / \mathrm{CdS} / \mathrm{CIGS} / \mathrm{W}$ нетоксичним шаром ZnSe за допомогою програмного забезпечення SCAPS-1D. Характеристики $J-V$ модельованої структури показують, що ефективність сонячного елемента збільшуеться з 23,23 \% до $23,58 \%$ (при $V_{o c}=0,8202 \mathrm{~B}, J_{s c}=34,86 \mathrm{~mA} / \mathrm{cm}^{2} \mathrm{i} \mathrm{FF}=82,49 \%$ ) завдяки використанню шару ZnSe. Збільшення ефективності елемента пояснюеться зменшенням поглинання фотонів у буферному шарі внаслідок більшої ширини забороненої зони шару ZnSe. Додатковий тонкий шар був вставлений між CIGS i зворотним контактом (W) для усунення рекомбінації на задній поверхні. Цей новий шар забезпечив додаткове тунелювання дірок, що призвело до збільшення ефективності сонячного елемента до 24,64 \%. Крім того, була зроблена спроба дослідити залежність ефективності сонячного елемента на основі CIGS від робочої температури.
\end{abstract}

Ключові слова: CIGS, Буферний шар, Шар задньої поверхні, Температура, SCAPS-1D. 